\title{
The Boyen Fortress: structural analysis of selecting complementary forms of use for a proposed adaptive reuse project
}

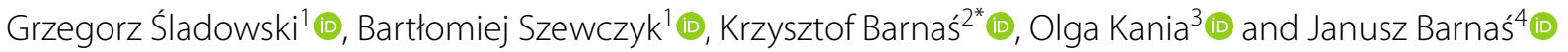

\begin{abstract}
Extending the life cycle of heritage buildings through their adaptive reuse can ensure their survival and is concordant with the policy of sustainable development. Selecting a new form of use for heritage building adaptive reuse projects is a multidimensional process that can be significantly aided by multi-criteria decision-making approaches. In this paper, the authors have proposed a hybrid form of structural analysis, which is a formulation of a multi-criteria approach to the analysis of complementary forms of use for a complex of historical buildings, to be used during the early planning stages of adaptive reuse projects for heritage building complexes. The approach has been demonstrated on the example of the Boyen Fortress complex in Giżycko, Poland. The outcome of the analysis indicated that the highest share of floor space to be adapted should be dedicated to exhibition spaces, which is justified concerning cultural heritage benefits. This approach can be of significant aid to decision-makers during adaptive reuse project planning phases, thereby facilitating the continued survival of heritage sites.
\end{abstract}

Keywords: Historical buildings, Adaptive reuse, Multi-criteria analysis, Decision making trial and evaluation laboratory—DEMATEL, Analytic network process-ANP, Complementary forms of use

\section{Introduction}

Most historical buildings have lost their original forms of use because they are no longer needed in their original forms in the present day. The development of civilisation has caused both needs and forms of satisfying them to change fundamentally. This fact has caused many abandoned historical buildings to undergo degradation.

One chance to improve this situation is the adaptive reuse of historical buildings, understood as making them suitable for other purposes than those that they previously fulfilled, i.e. their adaptive reuse [1].

The process of extending the life cycle of historical buildings associated with their adaptive reuse not only generates benefits to property owners (e.g. a good

\footnotetext{
*Correspondence: krzysztof.k.barnas@gmail.com

${ }^{2}$ Department of Urbanism and the Architecture of City Structures,

Cracow University of Technology, Kraków, Poland

Full list of author information is available at the end of the article
}

location, attractive appearance, financially advantageous purchase of property), but, in accordance with the concept of sustainable development, facilitates the survival of historical substance for future generations. Architectural conservation in the aspect of sustainable development is associated not only with typical conservation measures focused on a building's historical substance, but also on efforts linked with broadly understood urban regeneration [2, p. 661-668]. A comprehensive (in a societal, economic, environmental-protection-related and cultural-heritage-related aspect) process of the protection of historical monuments through restoring them to their former functions or assigning new ones to them, can become a part of the urban regeneration of a given urbanised area that has, for various reasons, become decayed, leading to a critical state and disrupting its proper functioning.

Adaptation and modernisation forms vary depending on the size of a building, its technical condition, cultural 
value, and other characteristics that arise from its original form of use (e.g. its functional and spatial structure, structural and material properties, location and the qualities of its surroundings). Furthermore, not every historical building is suitable for every form of use in terms of its functional and spatial layout, and while certain buildings afford a certain degree of flexibility in this regard, it is a factor that cannot be disregarded. Assessing a building's suitability for adaptation is therefore one of the cornerstones of the early stages of selecting a new form of use for any building, historic ones included. Another consideration is the identity of the place, which can further constrain the decision-maker's options [3]. Legislation and regulations applicable to conservation are also a significant factor, as indicated by Elsorady [4]. MCDM methods support human decision-makers by presenting to them a clearer picture of the decision problems they face, as based on the opinions of experts. However, they are not intended to replace human agency in decisionmaking, as the final decision is always made by a human being.

During the preparation of an adaptive reuse project, selecting the new functions that a historic building is to feature can be considered difficult as it requires numerous interdisciplinary factors (criteria) to be considered. This decision-making process, which involves multiple criteria, demands that decision-makers process and assess both measurable and difficult-to-measure data. Measurable data can include technical and financial information, while the data that is difficult to measure can be the rank of cultural heritage the structure in question represents.

Decisions have the character of a number so as to enable decision-makers to choose an alternative or group of alternatives from a preset group thereof [5]. This necessitates that information about a building be converted into numerical form. However, some among the architectural conservation community voice critical opinions about converting the characteristics of heritage sites into numerical values, despite the fact that such approaches have been used for centuries, e.g. by Vicq d'Azyr in his instruction from 1793 [6]. Objective methods of selecting values that can be used to describe heritage sites and assess them should be sought [5]. Numerous authors studying the field of architectural conservation $[5,7$, 8] suggested the application of Multi-Criteria Decision Analysis (MCDA) methods to do so $[9,10]$. These expert-opinion-based methods enable processing data pertaining to attribute and indicator values that apply to historical buildings and account for a range of possible uniquely defined decision alternatives. These elements are presented synthetically, either in a hierarchical or network-based dependence model. This defines the direction and manner of analysis, which can combine and process qualitative and quantitative data at the same time. Some algorithms used in these methods include expert opinion coherence control mechanisms. This enables the formulation of group expert opinions on various subjects, including interdisciplinary values.

The literature includes decision-making models focused on: historical structure assessment [11, 12], the need for their classification [13, 14] and setting priorities concerning funding and performing work on heritage buildings [8, 15-24]. Many scholars have also analysed spatial planning aspects in architectural conservation [11, 25-27]. A large body of the literature has been devoted to choosing conservation technologies and materials, either in adaptive reuse projects or as a specific subject [28-31]. In the last two years, comprehensive literature reviews were presented by Morkunaite et al. [32], Pavlovskis et al. [33], as well as Nadkarni and Puthuvayi [34], thus demonstrating the dynamic development of this field.

Ustinovičius and Jakučionis [7] analysed the renovation of historic structures in Vilnius, Lithuania, analysed potential functions using multi-criteria approaches in adaptive reuse projects. Their proposal was based on the TOPSIS method (Technique for Order Preference by Similarity to an Ideal Solution). The TOPSIS method has had a fuzzy extension developed and continued by Zavadskas and Antuchevičienè [35, 36], while Fuentes [37] used the weighted sum method to assess the possible reuse of four heritage sites in Spain. Wang and Zeng [38] explored form of use selection in the case of two heritage sites in Taipei, Taiwan. They employed the ANP method (Analytic Network Process) as a tool of multicriteria analysis, in conjunction with structural modelling. Another method used to select new forms of use is the "Choquet" integral, applied by Breil, Giove, and Rosato [39] and Giove, Rosato and Breil [40], who used to explore this problem on the example of the Arsenal building located in Venice, Italy. Multi-Attribute Value Theory (MAVT) was used by Ferretti, Bottero, and Mondini [41] to analyse a number of historical buildings in Turin, Italy, in terms of their capacity to house a given set of forms of use. Radziszewska-Zielina and Śladowski [42] also used MCDA methods to analyse the problem of selecting a form of use for a historical building-the Great Armoury in Gdańsk, Poland. They developed a fuzzy extension of the WINGS method (Weighted Influence Non-linear Gauge System) with the aim of modelling the imprecise, incomplete and uncertain character of data processed by experts in this process.

In the literature the vast majority of methods of multicriteria analysis was used to support decision-making in cases focusing on individual historical buildings. There is only a small number of publications concerning the 
adaptation of historical sites formed by a larger complex [43]. In order to prolong the life-cycle of buildings (by selecting new forms of use) that form a complex of buildings, it is justified to consider a larger number of mutually complementary forms of use instead of only a single one. The specificity of such a decision-making problem requires a system-based approach that will feature an analysis of elements (decision-making criteria, variants of new forms of use) and the relationships between them. The character of the problems requires taking into account not only the relationships (external dependencies) between the criteria and the variants of new forms of use, but also co-dependent relationships (internal relationships) within the set of selection criteria and the set of decision variants that will affect each other. Viewing the decision-making problem in this manner undoubtedly requires a comprehensive network-based approach to multi-criteria analysis, instead of a hierarchical one. In the literature we can find examples of decision-making models of the selection of a new form of use for a historical building in which the network structure of the system being analysed was taken into consideration, but in which interdependencies-due to the character of the problem (the selection of only one variant of a form of use for a building) only applied to decision-making criteria and not the variants of the form of use [38, 42]. In addition, it should be noted that the literature on the multi-criteria selection of new forms of use lacks models that would account for both positive and negative impact of inter-element influences. The multi-objective character of criteria and the complementarity of new forms of use selected for a given historic site forces the decisionmaker to account for this.

Due to inherent limitations of MCDA methods, researchers make attempts to enhance them either by improving available methods, or combining them into hybrid methods [44]. A promising avenue of improving these methods has been identified in approaches that focus on fuzzy logic, as presented by Radziszewska-Zielina and Śladowski [42], Macias-Bernal et al. [45] and others [46-48].

\section{Research aims}

This paper presents a proposal of an innovative and original multi-criteria approach to analysing the percentage share of complementary forms of use within a complex of historical buildings that can prove useful in preparing initial feasibility studies of adaptive reuse projects. Below is a list of features that make the proposal presented in this paper original and innovative:

- The proposed approach accounts for inter-criteria, inter-alternative and criteria-alternative dependen- cies in the analysis. Previous versions only allowed for inter-criteria dependencies and the impacts exerted by alternatives/variants on criteria.

- Instead of only relying on impact strength, expressed in its value always being either positive or zero, the proposed approach accounts for impact polarity, namely whether said impact is positive or negativeadverse or beneficial. This significantly enhances the DEMATEL method by accounting for positive and negative internal impacts in criteria and alternative selection, as well as for external impacts as feedback between these sets. The classical version of this method does not account for this distinction, which can lead to less realistic and intuitive analysis results.

In addition to the above, this paper proposes the use of a combination of the DEMATEL method, enhanced as presented, with the ANP method, thus creating a hybrid, network-based approach. It can be used to identify a set of complementary uses in the planning of an adaptive reuse project focusing on a historical building complex. The proposal has been backed with an analysis of the selection of a number of alternatives of complementary uses for the Boyen Fortress complex, located in Giżycko, Poland. As criteria and alternatives need to be formulated individually in every case, and due to most historical buildings being unique, it can be argued that a single case is sufficient for demonstration.

An overview of the original elements of the proposed approach and how they compare with previously used approaches has been presented in Fig. 1. Figure 1a is an illustration of the traditional approach: based solely on impact strength, with one-sided impacts by alternatives/ variants on criteria, with criteria affecting each other. In the proposed approach, presented in Fig. 1b, criteria also impact alternatives, the alternatives themselves impact each other, and all impacts are analysed in terms of strength and polarity.

\section{Presentation of the multi-criteria decision-making problem-materials and methods}

Selecting an alternative of a form of use during the planning of a historical building's adaptive reuse is a complex decision-making problem. The decision-maker must account for numerous independent and interdisciplinary factors (criteria).

Based on a review of the literature-Affelt [49], Radziszewska-Zielina and Śladowski [50], Vodopivec, Žarnić, Tamošaitienè, Lazauskas and Šelih [22], Skłodowski [5], Loli and Bertolin [44]-the authors listed the most commonly occurring selection criteria associated with the adaptation of historical buildings to new forms of use. This selection was also discussed with 


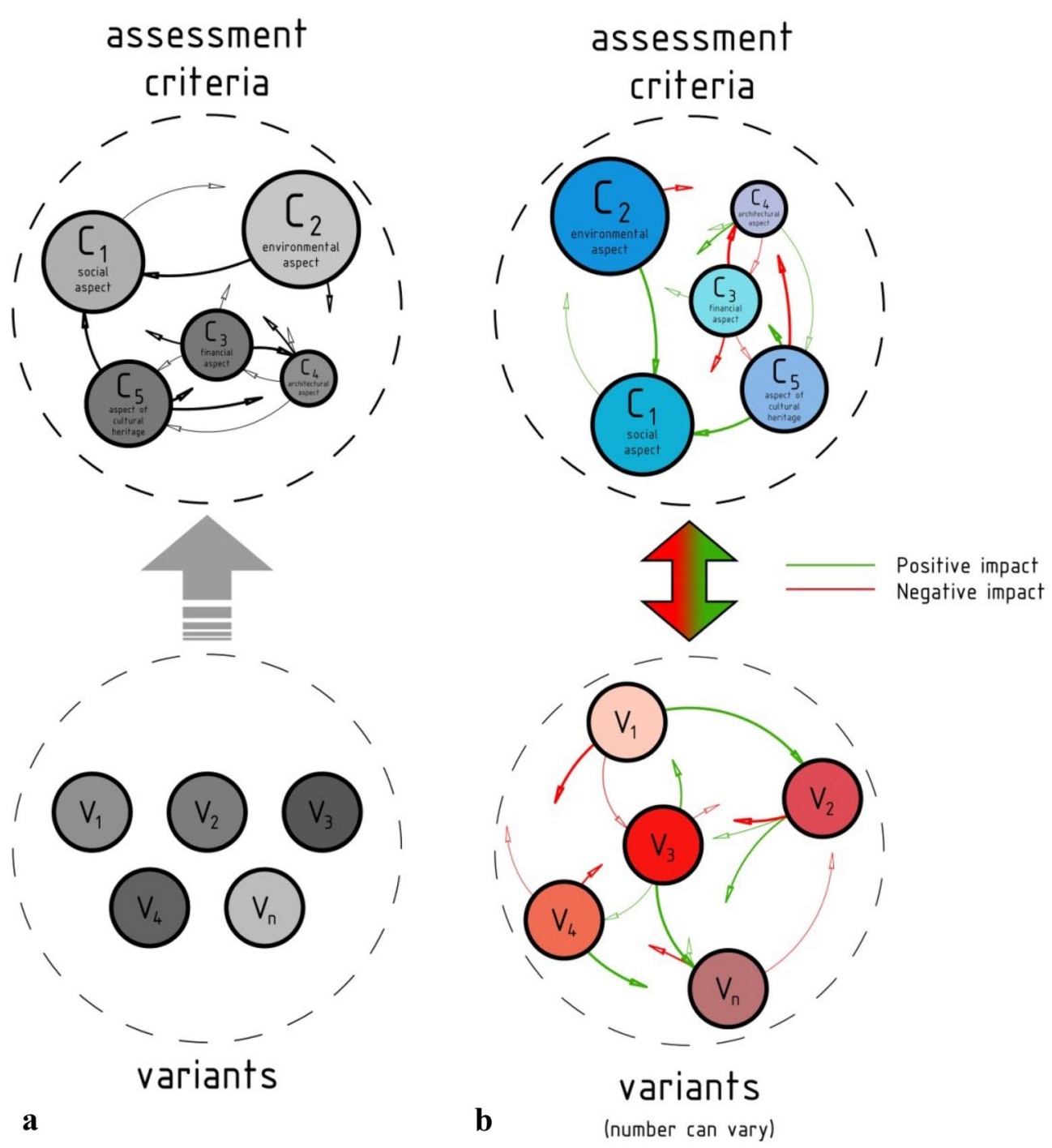

Fig. 1 Concept schemes for systems for a network-based approach to the multi-criteria problem of the selection uses in the adaptation of historical buildings a for the selection of a single variant of a building's use $[38,42]$, $\mathbf{b}$ for the selection of numerous complementary uses, along with determining their percentage share within the building or complex of buildings undergoing adaptive reuse, while accounting for positive and negative impacts

experts from such disciplines as architecture, economics, sociology, architectural conservation and civil engineering. Ultimately, five main criteria that possess a universal character were selected for the decision-making model (Table 1).

The aforementioned set of criteria, which can be considered universal to a certain degree, can be used to perform analyses during the stage of the preliminary feasibility study of a construction project. The set can be expanded to include additional criteria, whose occurrence will be determined by the specificity of a given historical building. For the purposes of detailed discussion, a deconstruction of every criterion can be performed by subdividing it into subcriteria, however, the precision level of the analysis should always be adapted to the amount of information at a decision-maker's disposal during the stage of the decision-making process.

When analysing the definitions of the criteria presented above, it can be easily seen that the descriptions of some of the criteria mutually overlap, which justifies the necessity to take interdependencies into account over the course of the multi-criteria analysis, including so-called feedback loops between these criteria. This interpretation leads to the adoption of a network-based character of relationships between them instead of the standard, hierarchical one. In order to synthetically describe and 
Table 1 Set of benefit criteria used to select the set of mutually complementary uses for the Boyen Fortress in this study

\begin{tabular}{|c|c|}
\hline Benefit criteria & Characteristics \\
\hline$C_{1}$ Economic benefits & $\begin{array}{l}\text { Benefits obtained thanks to returning neglected and abandoned historical buildings to use through adapting them to a } \\
\text { new form of use, which can lead to: an increase in property value, the generation of income through using the buildings } \\
\text { in economic activity. (Original definition) }\end{array}$ \\
\hline$C_{2}$ Benefits to society & $\begin{array}{l}\text { Benefits obtained thanks to reinforcing the feeling of identity and national integrity (the emotional bond between a society } \\
\text { and historical buildings as a testament of a past period), providing a sense of safety by appropriating abandoned build- } \\
\text { ings that fall prey to vandalism, uncontrolled occupancy and converting them to purposes that are beneficial to society } \\
{[49,50]}\end{array}$ \\
\hline $\begin{array}{l}\mathrm{C}_{3} \text { Benefits associated } \\
\text { with the protection of } \\
\text { the environment }\end{array}$ & $\begin{array}{l}\text { These benefits are possible to obtain as a result of extending the life-cycle of the material substance of historical buildings. } \\
\text { They are obtained by limiting construction waste, reducing energy consumption, limiting the emission of harmful sub- } \\
\text { stances. They are thus measurable benefits that cannot be obtained when constructing new buildings. The protection of } \\
\text { the environment is also affected by the potential improvement of the energy effectiveness of historical buildings during } \\
\text { occupancy. (Original definition) }\end{array}$ \\
\hline $\begin{array}{l}\mathrm{C}_{4} \text { Benefits associated } \\
\text { with the protection of } \\
\text { cultural heritage }\end{array}$ & $\begin{array}{l}\text { Benefits associated with the protection of cultural heritage are the result of preserving and restoring the past cultural } \\
\text { characteristics of historical buildings and their popularisation. Additional beneficial factors concerning cultural heritage } \\
\text { are linked with the knowledge that can be gained during the process of the refurbishment of historical buildings which in } \\
\text { turn leads to the obtaining of broader knowledge of buildings and increasing the amount of experience of the architec- } \\
\text { tural conservation community }[49,50]\end{array}$ \\
\hline $\mathrm{C}_{5}$ Architectural benefits & $\begin{array}{l}\text { Benefits associated with the architectural and construction-related aspects of the adaptation of buildings which affect their } \\
\text { capacity in terms of utility and installations-making it possible to make full use of the buildings. These benefits affect the } \\
\text { functional effectiveness of the buildings and their comfort of use. (Original definition) }\end{array}$ \\
\hline
\end{tabular}

analyse the decision-making problem presented above, it is necessary to select the appropriate tool that can make it possible to properly model and analyse the dependencies between the decision-making criteria and variants being discussed.

The concept of systems as complex objects composed of different elements between which there are certain relations (dependencies) lies at the foundation of many methods of multi-criteria analysis. One effective concept of reflecting such a system is structural modelling-a set of various techniques that make it possible to understand the properties of complicated systems, including decision-making problems [51]. The concept schemes for systems for a network-based approach to the multicriteria problem of the selection of a form of use in the adaptation of historical buildings have been presented on (Fig. 1).

The influence of decision variants on criteria is a measure of the degree to which the goals of represented by each criterion are achieved. The network-based structure of the relationships between elements in the system being discussed further defines the weight of the criteria (different sizes of the circles representing the criteria) as well as the strength of mutual relationships (symbolised by the different lineweights of the arrows) between the elements of this system.

It can be observed that historical buildings are increasingly often being adapted to numerous different uses instead of a single use, with the uses in question affecting each other to some degree. Thus, for the case presented above, the result of the multi-criteria analysis of the selection of a form of use for a historical structure will not be the selection of a single use, but rather a recommendation of numerous alternatives of complementary functions/uses along with determining their percentage share in the building or complex being subjected to adaptation. This is why the adopted a network-based structure of the relationships (whose layout is dependent on specific decision-making problems being analysed) between the criteria was supplemented by a co-dependent set of variants of proposed new uses for the historical structure and that affects the criteria above while also accounting for possible positive and negative impacts between them (Fig. 1b).

As for alternative selection, they:

- Have to be defined individually for every case,

- They should be potentially complementary,

- They should be functions/building uses that the structures under analysis can be adapted to (i.e. they must be permissible),

- They must align with the preferences of the developer/owner, and comply with land use regulations and conservation guidelines.

The alternatives analysed in this paper have been characterised in "Formulating the decision-making problem - definition of permissible building use alternatives" section. The uses that have been selected for analysis-hotel, exhibition spaces, commercial spaces, administrative spaces and sports and recreation-can be considered desirable from the standpoint of a municipal, 
institutional decision-maker intending to renew a major monument and as such they reflect the current situation of the presented case study.

The dependencies, impacts, their strength and polarities were defined by a panel of experts who were surveyed for this purpose. The experts were informed about the monument they were defining these elements for. A more detailed overview of this process has been presented in "Case study" section.

\section{Modelling and structural analysis of the problem}

The literature features numerous modelling and structural analysis methods that have been applied on a range of decision-making problems. The most prevalent methods include: ANP [52] (Fuzzy Analytic Network Process-Saaty, 1996), DEMATEL (Decision Making Trial and Evaluation Laboratory [53]) and WINGS (Weighted Influence Non-linear Gauge System [10]). These methods model dependencies between system elements using the directed graph, whose vertices represent system elements and its arches determine the relationships (influence) between them. The system modelling and analysis procedure used in these methods is based on similar algebraic mechanisms. Input ratings are entered into a matrix, which returns input values for the analysed model through the sum of all exponents in a liminal sense. The methods in question, due to having the same formal foundations, produce similar results. Therefore, when selecting the method with which to perform multicriteria analysis of the problem presented in this paper, the key factor to be considered is their usefulness.

The effectiveness of these structural modelling methods can be enhanced via combining them into a hybrid form. The essence of a hybrid approach is to analyse a given decision problem using complementary methods, which were previously used separately. A hybrid decision-making system [54,55] enables the processing of different types of knowledge which use different methods of reasoning and aggregation, namely the comparing of information with different values and their presentation using an aggregated indicator. One example of a hybrid decision-making system is the combination of the DEMATEL method with the ANP method. The main benefit of combining these methods is based on the DEMATEL method enabling the definition of a cause-and-effect structure network of relationships between system elements (e.g. criteria and decision alternatives) while the ANP method can (via multi-criteria analysis) determine the priorities of these elements within the system. There are few examples of hybrid models that utilise the potential of the DEMATEL and ANP methods in the literature on decisionmaking problems in construction, e.g. Zhou, Bai and
Sun [56]. Hatefi and Tamošaitienè [57]. However, none of these cases referred to the adaptive reuse of heritage buildings.

The application of a hybrid DEMATEL/ANP method to analyse the multidimensional problem of adapting heritage buildings to new complementary forms of use requires development to include the following aspects which make this approach innovative in comparison to its classical form, which was applied in previously mentioned literature.

1. The need to account for both positive and negative impacts between model elements (criteria and decision alternatives) required formulating an extension of the DEMATEL method. The classical version does not account for whether a given relationship is positive or negative.

2. Apart from building the network structure of criteria interdependencies, the DEMATEL method was used to determine co-dependent relationships between the forms of use of the heritage building subjected to adaptive reuse as explored in the paper, which is to reflect their complementary character.

3. The DEMATEL method was also used to determine external relationships between the set of criteria and the set of the forms of use of the heritage building under analysis within the system. These relationships can appear as feedback in situations when the functions also determine criteria significance, which can be essential from the standpoint of analysing the problem in question.

4. The decision model structure described above was analysed using the ANP method. The analysis determined global priorities for form-of-use alternatives, whose value shall determine the optimal percentage share of these functions within the building or complex being adapted in reference to the adopted criteria.

As a result of accounting for the above, the general outline of the proposed approach shall be as follows, to commence after defining criteria and alternatives, which are hereafter referred to as system elements.

The first part, comprised of four steps, follows the DEMATEL method as enhanced in this paper.

- First, a group of purposively selected experts is asked to fill out a survey in which they verbally assess the impacts between the system's elements: their impact strength and polarity. The collection of expert opinions can be performed using the Delphi method.

- The indirect impacts between system elements and the polarity of said impacts is then calculated. 
- Based on the calculations, a network of positive and negative total impacts between system elements is formulated.

- This network is then used to calculate significance thresholds and select the positive and negative total impacts between system elements.

After the conclusion of this stage, the proposed approach switches over to the ANP method and it is used it to carry out the remaining four steps, associated with determining the significance of system elements and global priorities. These steps are as follows:

- First, the decision problem is decomposed into positive and negative impacts to create two separate pipelines for each. The following two steps are carried out separately for positive and negative impacts.

- A group of experts is once again asked to brainstorm and assess the significance of each element in terms of its positive and negative impact on other elements via pairwise comparison. As noted above, this is done separately for positive and negative impacts.

- Based on the above, local and global priorities concerning the elements are calculated based on pairwise comparisons, again separately for positive and negative impacts.

- During the final stage, the results of the previous stage are aggregated and sequenced, producing an output in the form of a set of percentage shares of complementary building uses that can be considered optimal in light of the criteria adopted.

For ease of reference, this scheme shall be presented in Fig. 2.

In the DEMATEL method, the tool used to model dependencies between system elements is the directed graph of direct impact, in which the graph's vertices represent system elements and links determine the direction and intensity of the impact of elements on one another. These impacts and intensities are defined by experts in a survey.

Building the system element dependency structure requires adopting certain assumptions following the DEMATEL procedure.

1. Relationships between elements within the system are characterised by their influence (impact), which can be expressed using numbers;

2. Impacts between system elements should account for direct and complex (indirect) impacts, arising from impact transitivity;

3. Indirect impacts that arise between more than two system elements can be determined approximately by two-element impacts.

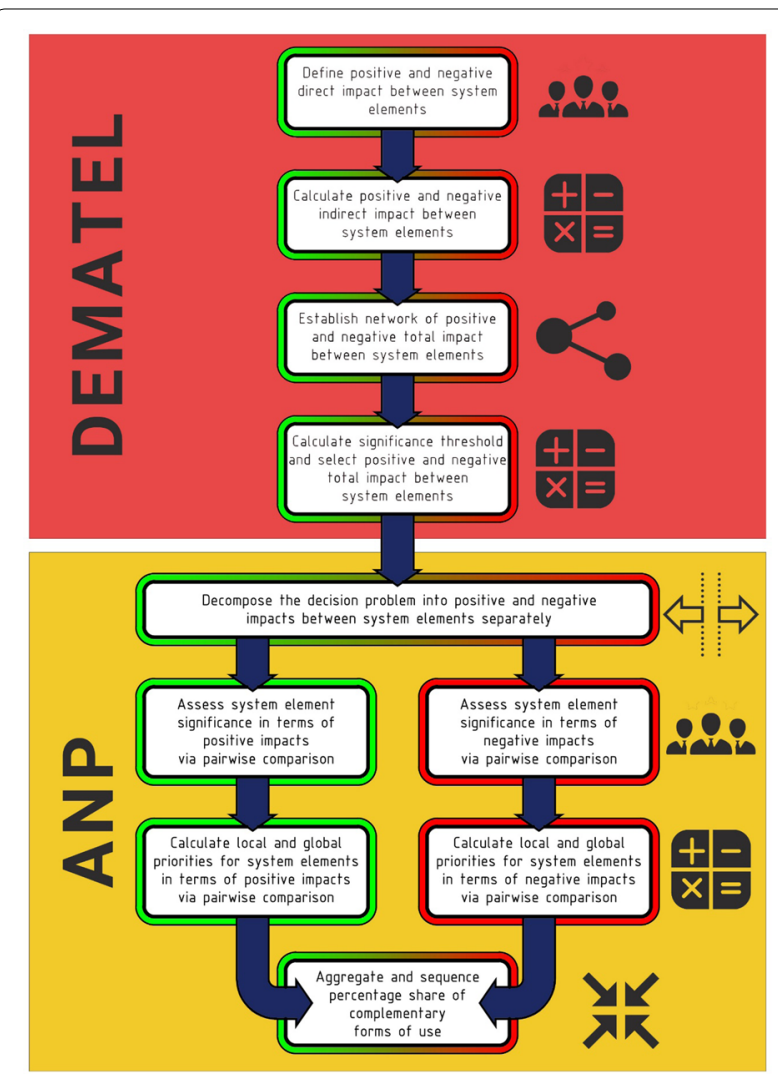

Fig. 2 Conceptual scheme of the method proposed in the study, displaying the steps performed using the DEMATEL and ANP methods, and accounting for positive and negative impacts

By impact transitivity, we understand the following dependency. If, within a given system, element $A$ has a direct impact on element $B$, which in turn directly impacts element $C$, then element $A$ exerts an indirect impact on element $C$, regardless of the possible additional direct impact exerted by element $A$ on element $C$. The greater the number of elements between elements $A$ and $C$, the weaker the direct impact.

The verbal description of the decision-making model is as follows:

1. Set $N$ is defined, comprising $n$ system elements under analysis, which are benefit criteria and alternatives featuring complementary forms of use in the adaptation of the given heritage structure,

2. Square matrix $C$ is defined, with $n \times n$ dimensions that defines the direct negative and positive impact between system elements. The structure of these dependencies is visualised by a directed graph showing direct impacts. 
In a survey, experts verbally define the polarity (positive or negative), intensity and direction of direct impacts between these elements. Positive impacts were given positive values, while negative impacts were given negative values. The experts' linguistic ratings are assigned numerical values based on a rating scale (Table 2).

In the matrix $D=\left\{a_{i j}\right\}, i, j=1, \ldots, n,($ of direct negative and positive impacts, as defined by the experts), elements $a_{i j}$, where: $i, j=1, \ldots, n$, for $i \neq j$, define the positive and negative impacts between system elements.

Apart from the system modelling principles that account for positive and negative impacts between said system's elements (decision criteria and alternatives), the structural analysis of this system also required extension.

Step 1. The direct impact matrix $D$ is standardised following formula (1).

$$
C=\frac{1}{\mathrm{~s}} D
$$

wherein the standardising factor is determined following formula (2).

$$
s=\max _{i=1, \ldots, n}\left\{\sum_{j=1}^{n}\left|a_{i j}\right|\right\}
$$

This standardisation method guarantees the existence of the total (positive and negative) impact matrix $\mathrm{T}$,

Step 2. Based on a standardised direct impact matrix $\mathrm{C}$, e calculate the resultant total (positive and negative) impact matrix $T=\left\{t_{i j}\right\}$ is calculated following formula (3)

$$
T=C+\Delta T
$$

where: $\Delta T=C^{2}+C^{3}+\ldots C^{p}$ is the direct impact matrix that is the sum of the successive powers of standardised direct impact matrix $C$.

Table 2 Positive and negative impact intensity rating scale presented to experts

\begin{tabular}{lc}
\hline Linguistic assessment & $\begin{array}{l}\text { Numerical } \\
\text { value }\end{array}$ \\
\hline Highly positive & 3 \\
Medium positive & 2 \\
Low positive & 1 \\
No influence & 0 \\
Low negative & -1 \\
Medium negative & -2 \\
Highly negative & -3 \\
\hline
\end{tabular}

Taking advantage of the fact that $\lim _{p \rightarrow \infty} C^{p}=[0]_{n x n}$, ultimately, the total (positive and negative) impact matrix can be calculated based on dependency (4).

$$
T=\sum_{p=1}^{\infty} C^{p}=C(\mathrm{I}-C)^{-1},
$$

where I is a unit matrix.

Step 3. Aggregation of the group expert assessment based on an arithmetical average

$$
\bar{T}=\frac{1}{K} \sum_{k=1}^{K} T,
$$

where $K$ is the number of experts.

Step 4. The decomposition of total impact matrices into positive (6) and negative (7) impact matrices.

$$
\begin{aligned}
& t_{i j}^{+}=\left\{\begin{array}{cc}
\bar{t}_{i j}, & \text { if } \bar{t}_{i j} \geq 0 \\
0 & \text { otherwise }
\end{array}\right\}, \\
& t_{i j}^{-}=\left\{\begin{array}{c}
\bar{t}_{i j}, \quad \text { if } \bar{t}_{i j} \leq 0 \\
0 \text { otherwise }
\end{array}\right\},
\end{aligned}
$$

Step 5. The significance threshold of total impacts as an arithmetical average (accounting for "zero-value" impacts) separately for positive (8) and negative (9) impacts.

$$
\begin{aligned}
& p^{+}=\frac{1}{n^{2}} \sum_{i=1}^{n} \sum_{j=1}^{n} t_{i j}^{+}, \\
& p^{-}=\frac{1}{n^{2}} \sum_{i=1}^{n} \sum_{j=1}^{n} t_{i j}^{-},
\end{aligned}
$$

The resultant network structures of positive and negative impacts between the elements of the system under study shall form a basis for performing a multi-criteria analysis of the decision-making problem using the wellknown ANP method [50]. The result of the analysis shall take on the form of global priorities interpreted as a recommended percentage share of individual complementary building use alternatives within the historical structure under study.

\section{Case study}

\section{Description of the historical structure under analysis}

The authors selected the Boyen Fortress in Giżycko, Poland (Fig. 3) to be the case study. The Fortress was built in the years 1844-1856 on the order of king Frederick William IV of Prussia, who commissioned it to be built in April 1843 and had it named after General Hermann 


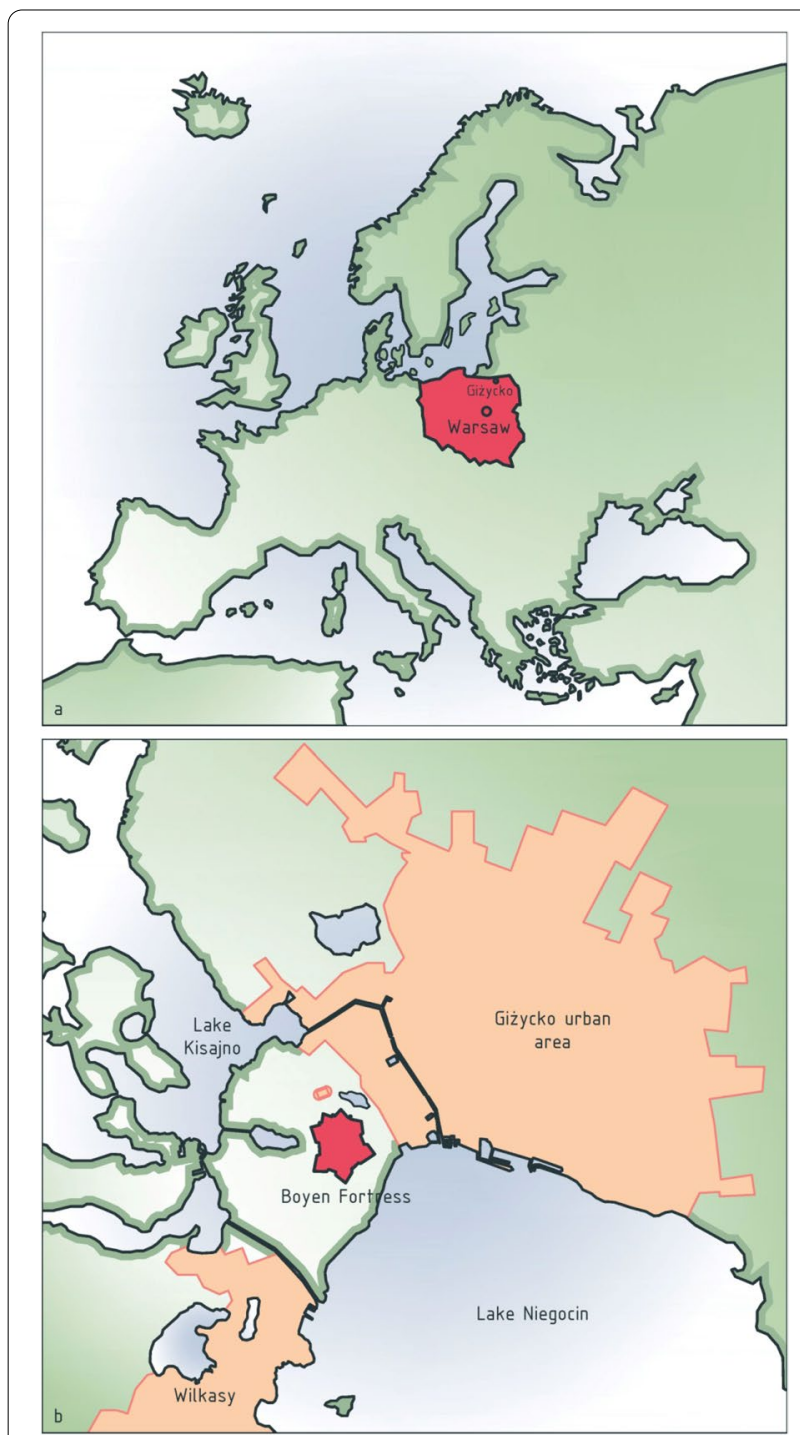

Fig. 3 Location of the Boyen Fortress. a Location of Giżycko within Poland and in Europe; $\mathbf{b}$ Location of the Fortress relative to the Giżycko urban area and the Kisajno and Niegocin Lakes

van Boyen [58]. It is a perfectly preserved example of the Prussian school of fortification. It constituted the main link of the chain of fortifications that blocked access to the Prussian state from the east, blocking the passage between Niegocin and Kisajno lakes-as it was placed on the so-called Giżycko Isle. The Fortress was surrounded with a stone and brick wall with a length of $2303 \mathrm{~m}$, resulting in an internal area of 100 ha. The Boyen Fortress played an active part in the First and Second World Wars, finding itself in the hands of the Polish Armed Forces in 1945, which then transferred it to the State Treasury in 1990. During the post-war period the Fortress was used for economic purposes. The Fortress is currently a complex of around 50 buildings and other structures which include both elements of its fortifications and the buildings located on the Fortress courtyard. It constitutes an attraction for tourists that come to Giżycko, currently housing, among other functions, a military museum. The fortress, as a part of Prussian and Polish military heritage, has been discussed at length by numerous authors, including Thorwald [59] and, separately, Bogdanowski $[60,61]$.

The Boyen Fortress has a plan typical of a bastion fort, comprised of an outer ring of casemated earthen and masonry Carnot walls with seven bastions and an inner courtyard with several free-standing buildings that served its garrison. The Fortress's walls have a combined length of $2303 \mathrm{~m}$, while its internal surface area is estimated at 100 ha. Six of the Fortress's seven bastions are named: three of the four northern bastions bear the names Leopold, Ludwig and Schwert (Sword), while the three southern bastions are named Hermann, Licht and Recht. The names of the bastions are a reference to the names of General Hermann von Boyen and the elements of his coat of arms. The interior of the Fortress complex can be accessed via four gates: the Powder Gate, the Water Gate, the Kętrzyn Gate and the Giżycko Gate. Each of these gates were protected by ravelins, which are currently overgrown by vegetation and can be hard to identify within the landscape. The terrain within the Fortress's walls was extensively remodelled so as to form a part of the defensive system of its walls. The terrain level along the walls is higher than that of the central courtyard and raised still along the outline of the walls themselves.

In total, around fifty individual structures form the Fortress, its walls excluded. The defensive structures include caponiers, observation domes, shelters, artillery battery emplacements and posterns, while infrastructural buildings include such structures like barracks buildings, a military hospital, storage buildings, granaries, a bakery, an arsenal and powder laboratory. Most infrastructural buildings are made of brick and have an elongated, rectangular plan. They are almost universally covered with gabled roofs covered with ceramic tiles. Their external finishes are primarily comprised of stone bases, veneer brick walls, and their architectural expression is typical of nineteenth-century Prussian military architecture, stressing utility and uniformity. The more distinctive architectural features of the Fortress's buildings include arched bifore. The tallest buildings have two storeys and a cellar.

The Fortress also features several structures that do not play a strictly defensive role, but due to their intended use during wartime, share the architectural and structural characteristics of defensive structures. One example of such a structure is the wartime barracks [62]. Giżycko's location within Poland, presented on a map of Europe, 
along with the Fortress' placement relative to the town shall be presented in Fig. 3, while the layout of the Fortress itself shall be presented in Fig. 4 .

Putting the Boyen Fortress to use has been a significant problem to stakeholders, who have undertaken a series of efforts in this regard over the recent years, to no effect. The authors performed a synthetic analysis of this problem of the selection of a form of use. Due to the size of the Fortress complex, it is necessary to diversify the function of the Fortress by selecting forms of use that can mutually complement each other and that will also positively affect the criteria of their selection.

\section{Formulating the decision-making problem - definition of permissible building use alternatives}

In order to build a decision-making model, the authors first defined the constraints, limitations and conditions that were characteristic of the analysed problem (Table 3).
The conditions presented above indicate that the Boyen Fortress is a very good example for the analysis of the selection of various mutually affecting forms of use that simultaneously influence a series of criteria of their selection, as a part of a single project. This is because, among other things, the fortress is a relatively large complex that constitutes a single thematic whole. It is due to this fact alone that the adaptation of this site should be performed comprehensively and holistically, in a manner that can ensure its functioning as an independent, cohesive functional organism. In order for this to happen, the forms of use that should be included in the fortress should complement each other and be quantitatively selected so that they can positively affect both other forms of use and the individual benefits that will be gained from the adaptation.

Based on the limitations and conditions outlined in Table 3, the authors proposed variants of complementary forms of use, with an assessment of the adaptation

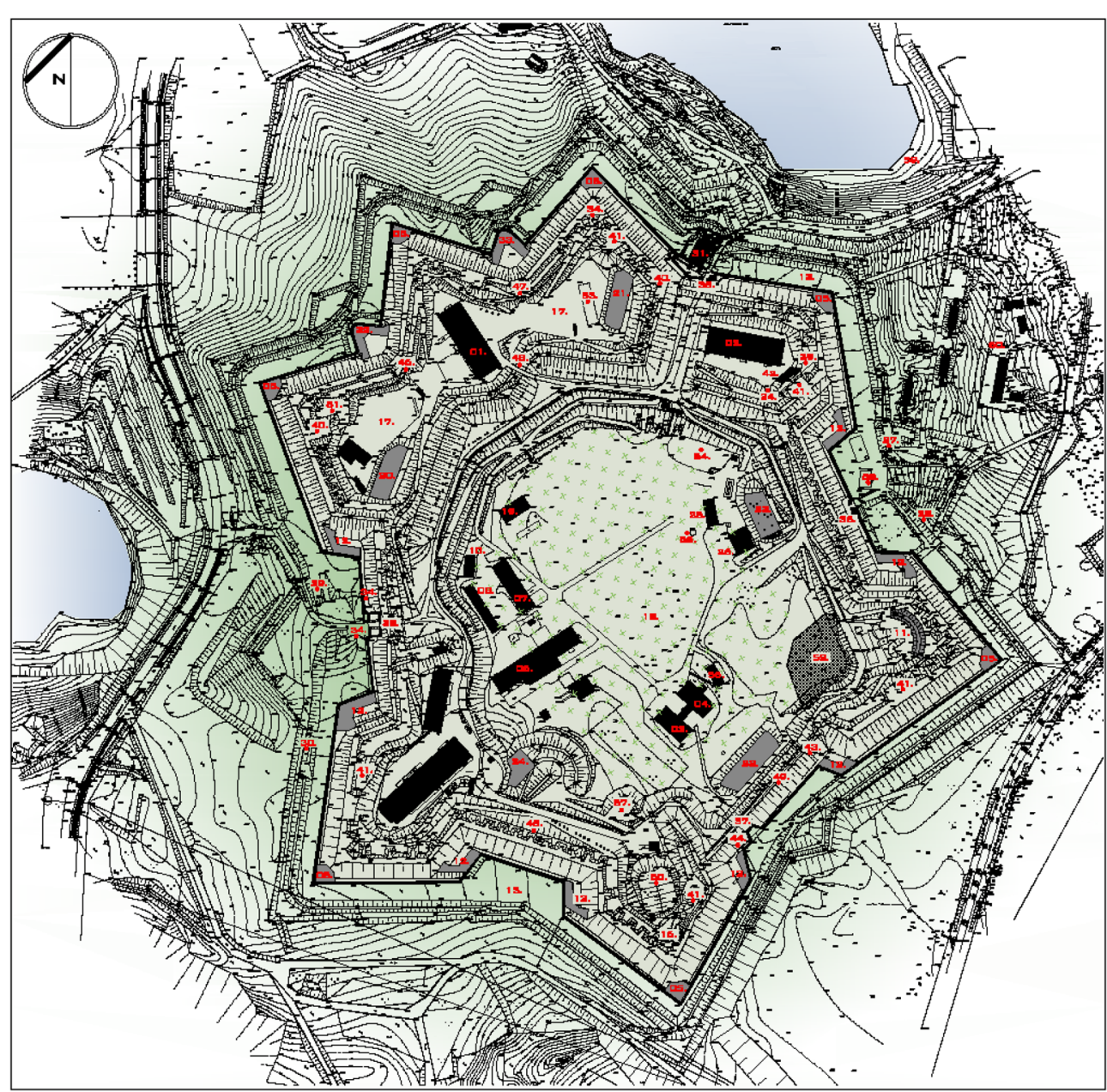

Fig. 4 Plan of the Boyen Fortress in Giżycko, Original in Polish, courtesy of IPG sp. z o.o 
Table 3 Limitations concerning the adaptation of the Boyen Fortress and their interpretation

\begin{tabular}{|c|c|}
\hline Limitations of adaptation & Interpretation \\
\hline Spatial character of the complex & $\begin{array}{l}\text { The Boyen Fortress is a complex that, in essence, features two types of buildings: the first type are the } \\
\text { buildings of the fortress courtyard, which can be considered detached masonry buildings typical } \\
\text { of the nineteenth century. The second type are the fortification structures, which are strictly tied } \\
\text { with the defensive character of the Fortress. This causes these structures to be located in highly } \\
\text { specific conditions, which place significant constraints on their potential in terms of adaptation } \\
\text { and functioning. The very fact of the Fortress being a historical site of great significance makes it } \\
\text { possible to take into consideration the adaptation of some of the buildings of the Fortress into } \\
\text { exhibition spaces, showcasing exhibitions associated with the military. On the other hand, the open } \\
\text { spaces of the Fortress courtyard provide an opportunity to introduce functions related to sports } \\
\text { and recreation }\end{array}$ \\
\hline Location of the complex & $\begin{array}{l}\text { The location of the Boyen Fortress possesses two fundamental characteristics. First, it is situated in } \\
\text { relatively close proximity to the centre of the town of Giżycko. Second, it simultaneously constitutes } \\
\text { an element that blocks the development of the town in the direction of the passage between } \\
\text { the Niegocin and Kisajno lakes, which has caused it to be surrounded by green areas from the } \\
\text { south and from the west. This means that while on the one hand it is placed in an area that is } \\
\text { highly advantageous in terms of access to the town centre, the complex has a specific cameral } \\
\text { character created by a buffer composed of greenery and water bodies. The location of the Fortress } \\
\text { is advantageous from the point of view of adapting a portion of its buildings for commercial and } \\
\text { hotel-related functions }\end{array}$ \\
\hline Historical and heritage value & $\begin{array}{l}\text { The Boyen Fortress derives its historical value primarily from its defensive character, which leads to } \\
\text { the necessity of protecting its distinct spatial layout and the architecture of its buildings. This means } \\
\text { that introducing newly designed buildings should be kept at a minimum, while adaptation should } \\
\text { be performed in a manner that will not significantly disrupt its original character. Both of these } \\
\text { circumstances support adapting a portion of the Fortress into exhibition spaces }\end{array}$ \\
\hline Interference with the structural system & $\begin{array}{l}\text { Modifying the structural elements and layouts of the existing buildings of the Fortress is possible } \\
\text { under the condition of preserving their spatial character. Adapting the structures that constitute } \\
\text { parts of the fortifications to new forms of use will be the most problematic from this point of view, } \\
\text { as their very structure and size constitute an essential obstacle to freely altering their functional } \\
\text { layouts. This means that certain structures are insufficiently flexible in terms of their adaptation } \\
\text { potential, which means that functions whose facilities are relatively non-invasive and that feature } \\
\text { fundamental spaces that can be designed in a flexible manner can be placed there. Examples of } \\
\text { such forms of use include administrative spaces and certain types of sports and recreation spaces }\end{array}$ \\
\hline Conforming to current construction regulations & $\begin{array}{l}\text { Due to their variety, both in spatial and structural terms, as well as because of their original func- } \\
\text { tions, the individual structures that comprise the Boyen Fortress possess a clearly defined character } \\
\text { in terms of the possibility of adapting them to current construction regulations and technical } \\
\text { standards. Some structures, for instance those that are a part of the fortifications, possess insuf- } \\
\text { ficient access to sunlight, which makes them very difficult to adapt to forms of use like a hotel or } \\
\text { administrative spaces }\end{array}$ \\
\hline
\end{tabular}

potential of individual structures to each of these forms of use being presented in Table 4. As it can be seen from the assessment of the suitability of the structures for adaptation, each of the buildings can be assigned any of the five analysed forms of use. For instance, Fig. 5 shall present a conceptual design of the adaptation of one of the existing buildings of the Boyen Fortress to a commercial function (conference spaces) or an administrative function, thereby demonstrating that this structure can be easily adapted to different uses and as such the adaptive reuse of the buildings listed in Table 4 can be freely analysed.

Apart from the adaptation of existing buildings, the authors also considered the possibility of constructing additional buildings in order to supplement the analysed forms of use (Table 5). The conceptual design of a new conference and entertainment hall that could form a part of the adaptation of the Boyen Fortress has been shown in Fig. 6.

The decision-making problem in question in the analysed case study is focused on determining the percentage share of each of the complementary forms of use, with the proportions potentially forming a basis for designing the functional and utilitarian layout of the complex as a part of a possible design of the adaptation of Boyen Fortress.

\section{Multi-criteria analysis of the decision-making problem- Results}

In accordance with the proposed approach, the authors first gathered a 5-person group of experts with interdisciplinary knowledge in the fields of: architecture, economics, sociology, architectural conservation and civil engineering. They formed a purposive sample and had to possess at least fifteen years of interdisciplinary 
Table 4 Assessment of the suitability of buildings for adaptation to a hotel, exhibition spaces, administrative spaces and sports and recreation-related functions

\begin{tabular}{|c|c|c|c|c|c|c|c|}
\hline No & Building name & $\begin{array}{l}V_{1} \\
\text { Suitability } \\
\text { for a hotel }\end{array}$ & $\begin{array}{l}\mathrm{V}_{2} \\
\text { Suitability for an } \\
\text { exhibition space }\end{array}$ & $\begin{array}{l}V_{3} \\
\text { Suitability for } \\
\text { a commercial } \\
\text { function }\end{array}$ & $\begin{array}{l}\mathrm{V}_{4} \\
\text { Suitability for an } \\
\text { administrative } \\
\text { function }\end{array}$ & $\begin{array}{l}\mathrm{V}_{5} \\
\text { Suitability for a } \\
\text { sports and recreation } \\
\text { function }\end{array}$ & Floor area $\left(\mathrm{m}^{2}\right)$ \\
\hline 1 & Barracks & 3 & 3 & 3 & 3 & 2 & 2779.7 \\
\hline 2 & Barracks & 3 & 3 & 3 & 3 & 2 & 2779.7 \\
\hline 3 & Granary & 3 & 3 & 3 & 3 & 2 & 940.0 \\
\hline 4 & Granary & 3 & 3 & 3 & 3 & 2 & 940.0 \\
\hline 5 & Arsenal & 2 & 3 & 3 & 3 & 3 & 1953.6 \\
\hline 6 & Exercise building & 2 & 3 & 3 & 3 & 3 & 499.1 \\
\hline 7 & Artillery workshop & 2 & 3 & 3 & 3 & 2 & 210.7 \\
\hline 8 & $\begin{array}{l}\text { Homing pigeon } \\
\text { station }\end{array}$ & 2 & 3 & 2 & 2 & 2 & 305.2 \\
\hline 9 & $\begin{array}{l}\text { Black powder labora- } \\
\text { tory }\end{array}$ & 1 & 3 & 3 & 3 & 2 & 399.4 \\
\hline 10 & $\begin{array}{l}\text { Coach house and } \\
\text { stable }\end{array}$ & 2 & 3 & 3 & 3 & 3 & 371.6 \\
\hline 11 & Wartime barracks & 2 & 3 & 2 & 2 & 2 & 227.3 \\
\hline 12 & Wartime barracks & 2 & 3 & 2 & 2 & 2 & 211.3 \\
\hline 13 & Wartime barracks & 2 & 3 & 2 & 2 & 2 & 294.0 \\
\hline 14 & Wartime barracks & 2 & 3 & 2 & 2 & 2 & 217.1 \\
\hline 15 & Wartime barracks & 2 & 3 & 2 & 2 & 2 & 219.0 \\
\hline 16 & Bakery complex & 2 & 3 & 3 & 2 & 2 & 926.0 \\
\hline
\end{tabular}

Scale of the suitability for adaptation to a given function

3-high suitability (it is possible to adapt the structure to the given function while limiting interference with its material substance to a minimum), 2-conditional or low suitability (it is possibly to adapt the structure to the given function while significantly altering its substance and character), 1-very low or highly problematic suitability (the adaptation would cause an almost complete loss of the original character of the structure). Some of the Fortress' structures were not included in this analysis - such as the spaces at the tips of its bastions or certain caponiers. Their layout, as well as other specific conditions, e.g. lack of access to sunlight, made them highly inflexible in terms of adaptation capacity, which is why including them in the analysis made no sense

professional or academic experience in architectural conservation, gained while participating in major restoration projects with a budget of at least $€ 1,000,000$. The experts possessed detailed knowledge about the historical complex of the Boyen Fortress. Because the selection of experts is a deliberate, goal-oriented choice, their number does not need to depend on the size of the population, which in this case is difficult to assess. The count of the surveyed group is a result of the decision-maker's subjective belief that it is representative [63].

Surveys combined with heuristic methods were used to formulate and collect expert opinions to be fed into the algorithm. To formulate their opinions, the experts first participated in a survey that was followed by a round of brainstorming intended to make pairwise comparisons. The use of brainstorming in conjunction with MCDA methods was discussed by Vorobiev et al. [64] and Belton and Stewart [65], and as a part of Delphi and MCDAbased studies, such as that of Van Schoubroeck et al. [66]. Van Schoubroeck et al. specifically used brainstorming in the first round of their Delphi study, utilising MCDA methods (Best-Worst Scaling, BWS; Hierarchical Bayes,
AURORA) for the second round, an approach that bears certain similarities to the one proposed in this paper. In the proposed approach, experts were first asked to participate in a survey intended to identify impacts between system elements as a part of the enhanced DEMATEL section of the proposed method, which was followed by a brainstorming session that determined pairwise comparisons for the ANP section of the method.

For the purposes of modelling the structure of negative and positive relationships between elements (criteria and form-of-use alternatives), the experts performed a linguistic assessment of the influence between the benefit criteria, as well as between the decision variants, in addition to assessing the influence of the variants on these criteria and vice versa. The example opinion matrix for expert no. 1, based on the scale of linguistic assessments, has been presented in Table 6.

To determine the reliability of expert ratings, their concordance was verified using Kendall's W (Kendall's) coefficient of concordance, accounting for the presence of tied ranks (impacts between individual model elements could have been given the same ratings) [67]. The 


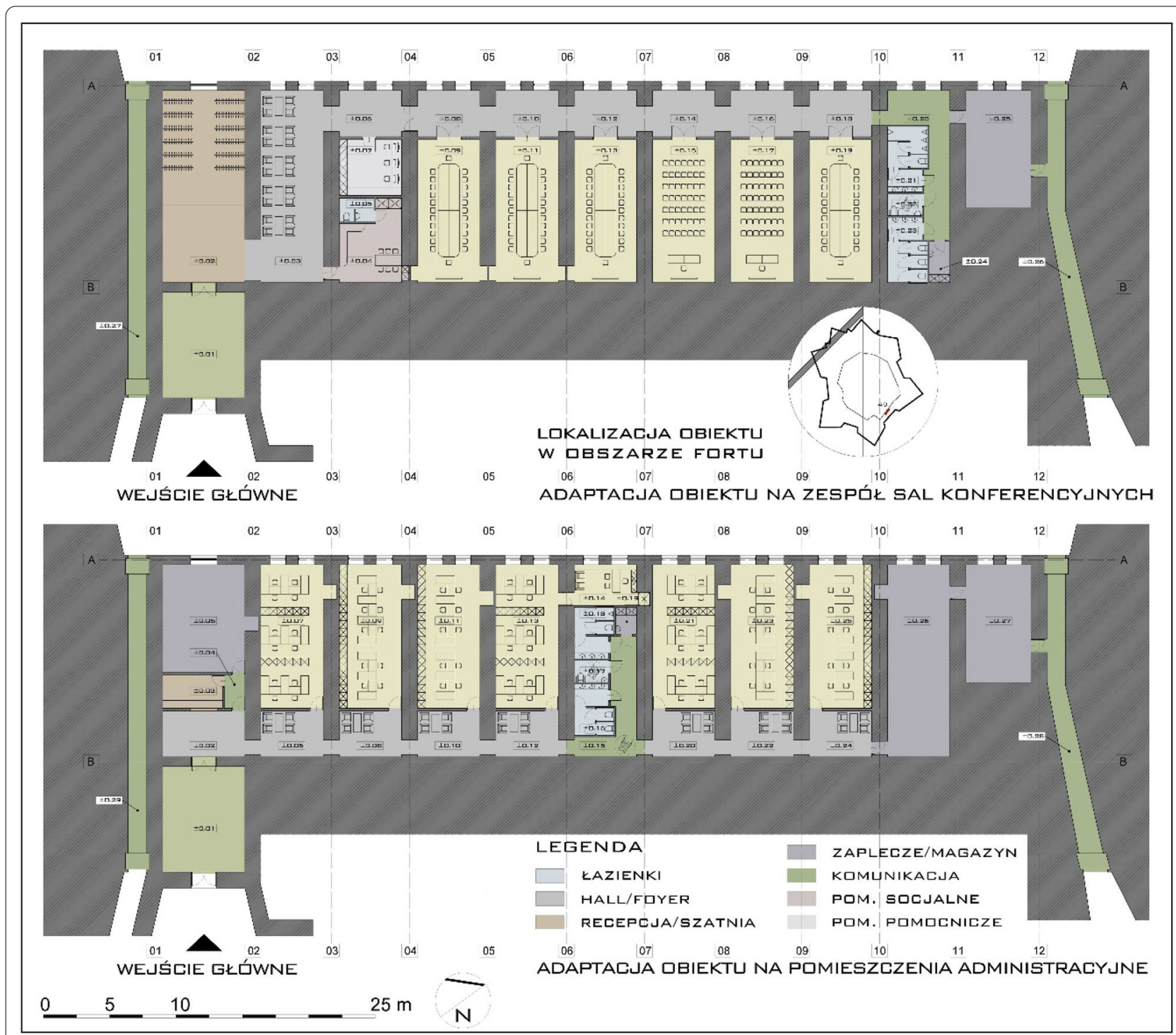

Fig. 5 Conceptual design of two versions of the adaptation of one of Boyen Fortress' buildings to different functions: a complex of conference halls or administrative spaces. Original in Polish. Source: courtesy of IPG sp. z 0.0

Table 5 Proposed newly designed buildings

\begin{tabular}{lllr}
\hline No & Building name & Purpose/function & ${\text { Fl. area }\left[\mathbf{m}^{2}\right]}$ \\
\hline 1 & Amphitheatre & Commercial/entertainment & 1800.0 \\
2 & Courtyard development & Entertainment/exhibition/commercial & $22,000.0$ \\
3 & Museum building (on the courtyard) & Exhibition & 2800.0 \\
4 & Administrative building (on the courtyard) & Administrative & 1000.0 \\
5 & Mixed-use building & Commercial/administrative/exhibition & 3000.0 \\
6 & Conference building & Commercial/administrative & 2000.0 \\
\hline
\end{tabular}




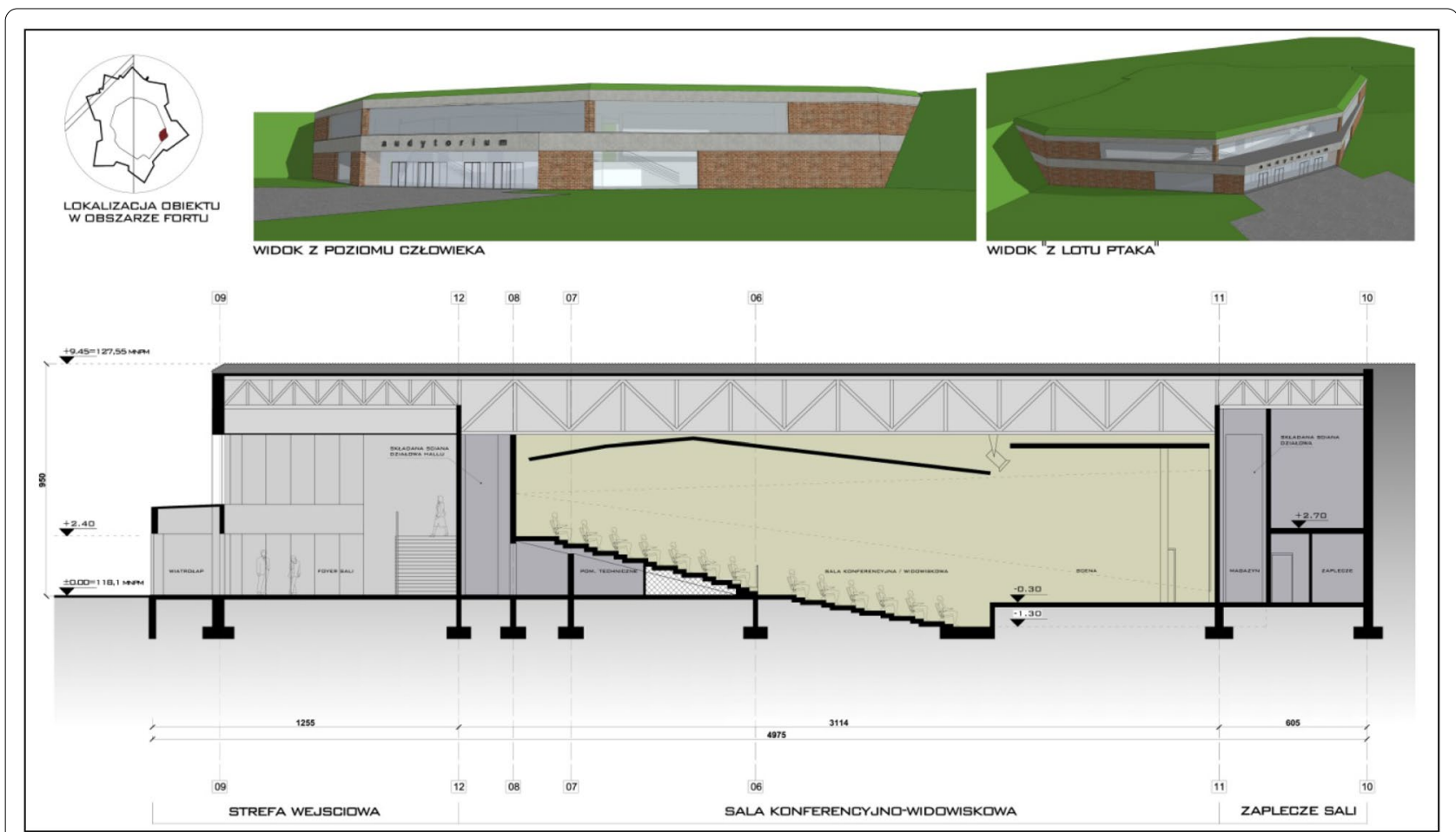

Fig. 6 Conceptual design of a newly designed building that could form a part of the adaptation of the Boyen Fortress. Original in Polish. Source: courtesy of IPG sp. z 0.0

Table 6 Linguistic assessment of the intensity of mutual influence between criteria and alternatives, as well as the influence of alternatives on the criteria, according to Expert no. 1

\begin{tabular}{|c|c|c|c|c|c|c|c|c|c|c|}
\hline Expert 1 & $C_{1}$ & $C_{2}$ & $C_{3}$ & $C_{4}$ & $C_{5}$ & $v_{1}$ & $v_{2}$ & $V_{3}$ & $V_{4}$ & $v_{5}$ \\
\hline$C_{1}$ & - & $L N$ & $\mathrm{HN}$ & $L N$ & LP & MP & LN & $\mathrm{HP}$ & LP & MP \\
\hline$C_{2}$ & $\mathrm{LN}$ & - & MP & $\mathrm{HP}$ & $\mathrm{NI}$ & MP & $\mathrm{HP}$ & $\mathrm{NI}$ & $\mathrm{NI}$ & $\mathrm{HP}$ \\
\hline$C_{3}$ & $\mathrm{MN}$ & $\mathrm{HP}$ & - & MP & MN & LN & $\mathrm{NI}$ & $\mathrm{MN}$ & $\mathrm{NI}$ & MP \\
\hline$C_{4}$ & $\mathrm{MP}$ & $\mathrm{HP}$ & MP & - & LN & $\mathrm{HN}$ & MP & $\mathrm{HN}$ & $\mathrm{NI}$ & $L P$ \\
\hline$C_{5}$ & $\mathrm{MP}$ & $\mathrm{NI}$ & MP & $\mathrm{LN}$ & - & MP & LN & MP & LP & LP \\
\hline$V_{1}$ & $\mathrm{HP}$ & $L N$ & $\mathrm{MN}$ & LN & $\mathrm{NI}$ & - & LP & $\mathrm{HP}$ & MN & LP \\
\hline$V_{2}$ & $L P$ & MP & MP & $\mathrm{HP}$ & MP & MP & - & MP & $\mathrm{NI}$ & LN \\
\hline$V_{3}$ & $\mathrm{HP}$ & LN & LN & $L N$ & MN & MP & LP & - & LP & $L P$ \\
\hline$V_{4}$ & $\mathrm{MN}$ & $L P$ & $\mathrm{NI}$ & $\mathrm{NI}$ & $\mathrm{NI}$ & $\mathrm{NI}$ & $\mathrm{NI}$ & $\mathrm{NI}$ & - & MN \\
\hline$V_{5}$ & MP & LN & HN & LN & LN & LP & MN & $\mathrm{HP}$ & $\mathrm{HN}$ & - \\
\hline
\end{tabular}

Scale: HP-highly positive, MP-medium positive, LP-low positive, NI-no influence, LN-low negative, MN-medium negative, HN-highly negative

Kendall's $W$ value for the expert ratings was $W=0.778$, which indicates that the experts were largely concordant. The chi-squared test was also performed to test the statistical significance of the concordance indicator, which resulted in the rejection of the zero hypothesis about there being no correlation between expert ratings, with the significance level being $\alpha=0.05$. It can thus be stated that the convergence of expert opinions was not coincidental.
After determining the total impact matrix using the enhanced DEMATEL method, the authors aggregated expert assessments by calculating an average total impact matrix (Table 7) with positive and negative impacts. The authors found impacts with a value no smaller than the average for the given impact matrix as significant-in the case of positive impacts, this was at least 0.006 , while in the case of negative impacts it was 
Table 7 Aggregated total impact matrix

\begin{tabular}{lcccccccccc}
\hline & \multicolumn{1}{c}{$\boldsymbol{C}_{\mathbf{1}}$} & \multicolumn{1}{c}{$\boldsymbol{C}_{\mathbf{2}}$} & \multicolumn{1}{c}{$\boldsymbol{C}_{\mathbf{3}}$} & \multicolumn{1}{c}{$\boldsymbol{C}_{\mathbf{4}}$} & \multicolumn{1}{c}{$\boldsymbol{C}_{\mathbf{5}}$} & \multicolumn{1}{c}{$\boldsymbol{V}_{\mathbf{1}}$} & \multicolumn{1}{c}{$\boldsymbol{V}_{\mathbf{2}}$} & $\boldsymbol{V}_{\mathbf{3}}$ & $\boldsymbol{V}_{\mathbf{4}}$ & $\boldsymbol{V}_{\mathbf{5}}$ \\
\hline$C_{1}$ & 0.001 & -0.002 & -0.019 & -0.005 & 0.007 & 0.012 & -0.007 & 0.020 & -0.003 & 0.010 \\
$C_{2}$ & 0.005 & 0.001 & 0.013 & 0.019 & 0.000 & 0.019 & 0.012 & 0.010 & 0.002 & 0.014 \\
$C_{3}$ & -0.011 & 0.018 & 0.001 & 0.010 & -0.005 & -0.001 & 0.009 & -0.017 & -0.006 & 0.013 \\
$C_{4}$ & 0.014 & 0.022 & 0.013 & 0.001 & -0.014 & -0.010 & 0.002 & -0.019 & -0.003 & -0.002 \\
$C_{5}$ & 0.009 & 0.004 & 0.018 & -0.007 & 0.000 & 0.015 & -0.015 & 0.018 & 0.011 & 0.010 \\
$V_{1}$ & 0.017 & -0.003 & -0.010 & -0.002 & 0.000 & 0.001 & 0.005 & 0.017 & -0.007 & 0.015 \\
$V_{2}$ & 0.008 & 0.021 & 0.009 & 0.022 & 0.013 & 0.006 & 0.000 & 0.017 & 0.005 & -0.003 \\
$V_{3}$ & 0.019 & -0.008 & -0.017 & -0.014 & -0.004 & 0.009 & 0.004 & 0.001 & -0.003 & 0.008 \\
$V_{4}$ & -0.018 & 0.005 & 0.009 & 0.006 & 0.003 & -0.006 & 0.001 & -0.002 & 0.000 & -0.003 \\
$V_{5}$ & 0.014 & 0.003 & -0.019 & -0.013 & -0.006 & 0.012 & -0.014 & 0.021 & -0.014 & 0.000 \\
\hline
\end{tabular}

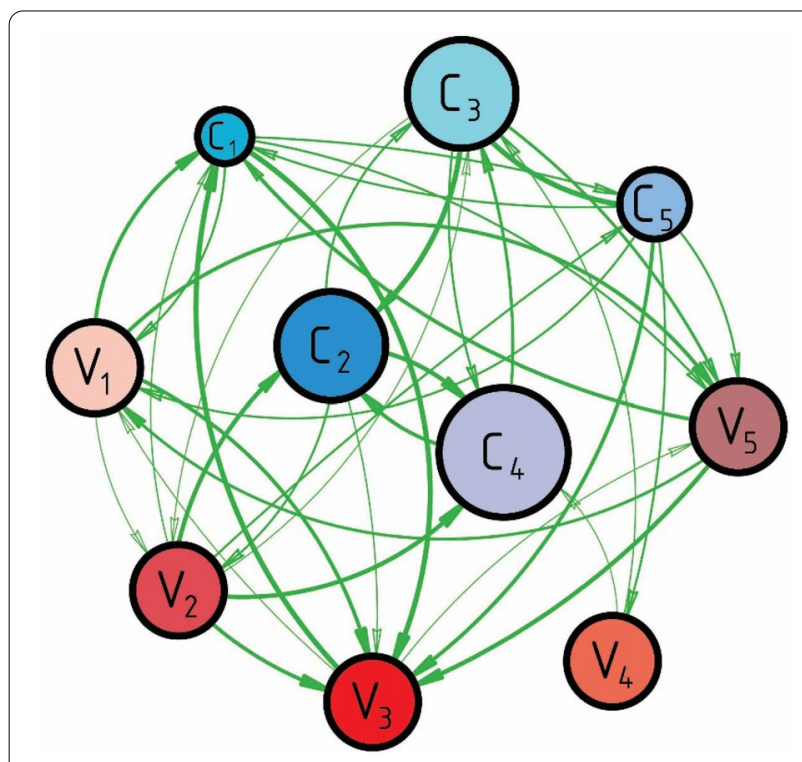

Fig. 7 Positive impact subnetwork

- 0.003 or less. The authors identified 41 significant positive and 28 significant negative impacts.

As a consequence, a structural decision-making model was built, based on the significant positive and negative impacts between criteria and alternatives that were identified. The subnetworks of positive and negative impacts have been presented in Figs. 7 and 8.

For the relationship structures presented above, the authors performed calculations associated with multicriteria analysis using the ANP method. The authors used Super Decisions software for this purpose, as it is a digital application enabling the use of the AHP and ANP methods (https://www.superdecisions.com/index.php).

Pairwise comparisons of each of the model's elements were performed jointly by a group of experts who had

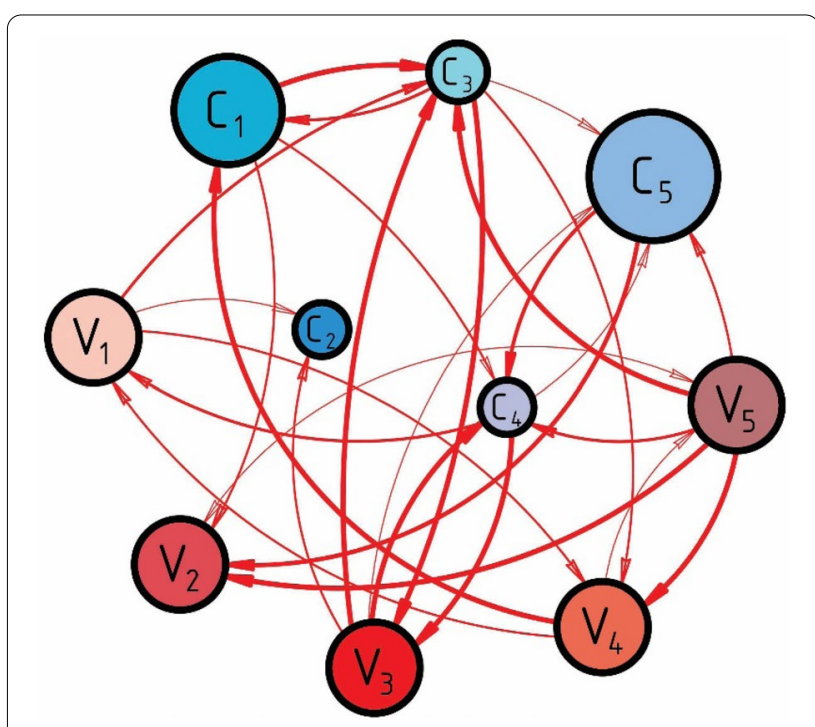

Fig. 8 Negative impact subnetwork

Table 8 Final analysis results

\begin{tabular}{lllll}
\hline Name & Benefits & Costs & $\begin{array}{l}\text { Additive } \\
\text { (probabilistic) } \\
\text { formula }\end{array}$ & $\begin{array}{l}\text { Additive } \\
\text { ranking }\end{array}$ \\
\hline$V_{1}$ Hotel spaces & 0.026 & 0.151 & 0.180 & 2 \\
$V_{2}$ Exhibition spaces & 0.764 & 0.128 & 0.548 & 1 \\
$V_{3}$ Commercial spaces & 0.052 & 0.273 & 0.042 & 5 \\
$V_{4}$ Administrative spaces & 0.121 & 0.288 & 0.056 & 4 \\
$V_{5}$ Sports and recreation & 0.037 & 0.160 & 0.174 & 3 \\
\hline
\end{tabular}

defined the impacts between alternatives and criteria. The final results of the analysis have been shown in Table 8. The presentation includes ratings given to alternatives in the context of their positive and negative impact, in addition to synthetic results calculated 
using an additive formula assuming a weight of 0.5 for positive and 0.5 for negative impacts. The proportion between the weights of positive and negative impacts can (depending on the decision-maker's preferences) be given different values.

\section{Discussion}

Exhibition spaces $\left(V_{2}\right)$ were shown to be the most beneficial. This alternative received the highest rating for positive impacts and the lowest rating for negative impacts. According to synthetic results, alternative 1 (hotel spaces) ranked second, due to its low rating for positive impacts, but a beneficially low rating in negative impacts. Alternative 3 (commercial spaces), was ranked the lowest, at fifth place. In the case of alternative 4 (administrative spaces) it had the highest negative impacts and the second-highest positive impacts, earning it fourth place via synthetic analysis. Alternative 5 (sports and recreation) scored average ratings for both positive and negative impacts, which earned it third place in the ranking.

Based on the final results obtained using the additive formula, the percentage share of each alternative in the floor area of the structure under analysis was defined. The highest share (ca. 55\%) of the adapted floor area should be assigned for use as exhibition spaces, which appears justified from the standpoint of benefits to cultural heritage. Hotel spaces and sports and recreation should be assigned ca. $18 \%$ of floor area each. These forms of use can complement the primary function, acting as a supplementary attraction and providing accommodations. Administrative spaces are necessary for the complex's proper functioning and managing the operations of the remaining four areas of activity. According to the analysis, this function should not occupy more than $6 \%$ of the total floor area of the complex. The smallest share of floor area should be assigned to commercial spaces (ca. $4 \%$ ) so as not to disrupt the character of the site, while also providing space for small stores and accompanying services.

A sensitivity analysis was performed for the model. Figure 9 shall present how the final results for each alternative changed depending on variations in weight for positive impacts. It can be observed that increases in weight corresponded with a more beneficial rating for exhibition spaces and, to lesser degree, for administrative spaces. The ratings for hotel and sports and recreation functions decreased. The rating for the commercial function remained at a relatively stable level. Exhibition spaces did not change their first place in the ranking regardless of the weight for positive impacts. Changes could be observed for the remaining alternatives. For instance, for a weight above 0.8 , administrative spaces moved to second place, outranking hotel

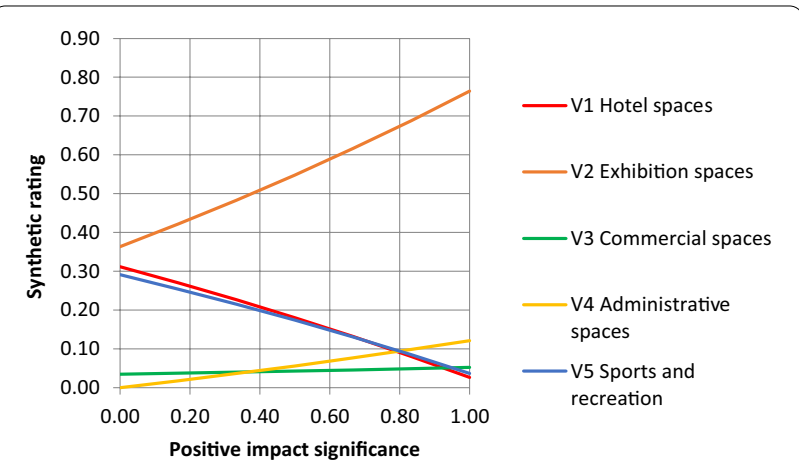

Fig. 9 Changes in synthetic results depending on positive impact significance

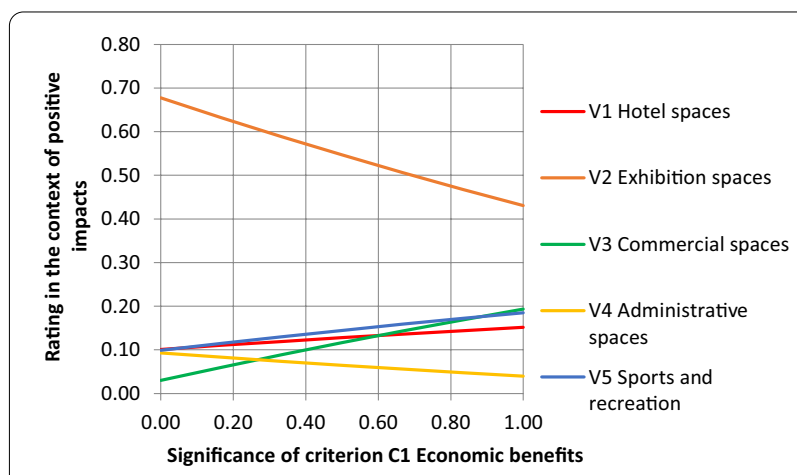

Fig. 10 Changes in ratings for alternatives in the context of positive impacts, accounting for changes in the weight of criterion $C_{1}$ economic benefits

spaces and sports and recreation, while the dominance of exhibition spaces become even more profound.

A sensitivity analysis was also performed to investigate the effect of changing the weights of individual criteria on the results. It demonstrated that the second alternative clearly dominated over the other alternatives, whose positions varied, each time. The combined share of the remaining alternatives ranged between 0.269 and 0.57 . Figure 10 shall present the changes in alternative ratings in the context of positive impacts with weight variations for criterion $C_{1}$ economic benefits. Changes in the weight for this criterion showed the greatest variation in the ranking of the second alternative. This rating ranged between 0.430 for a criterion weight of 1 and 0.678 for a criterion weight of zero. Despite this observation, this alternative maintained clear superiority over the remaining alternatives in each case. Figure 11 shall demonstrate the dependency between the ratings of each alternative in the context of negative impacts while accounting for changes in the weight of criterion $C_{1}$ economic benefits. 


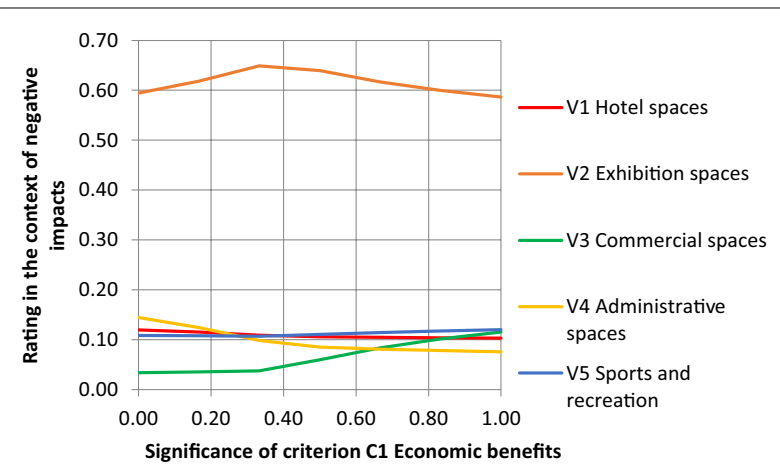

Fig. 11 Changes in ratings for alternatives in the context of negative impacts, accounting for changes in the weight of criterion $C_{1}$ economic benefits

The information obtained by the authors that has been presented above can be useful to a decision-maker during the stage of the initial feasibility study of a project of the adaptation of a complex of buildings to new, complementary forms of use. It can be argued that the introduction of complementary forms of use can improve the odds of a heritage complex's long-term survival. The better the configuration of these forms of use, the better these odds can be. From an architectural standpoint, selecting an optimal mixture of forms of use, while assigning them to functionally and spatially suitable buildings, can further aid in preserving heritage, as it can potentially lead to a lower degree of interference with its substance.

In the literature we can find numerous proposals of decision-making models and methods of performing multi-criteria analysis with the aim of supporting decision-making in terms of adaptation work performed on historical buildings. However, these approaches are usually limited to the selection of a single form of use for the analysed building. The selection of several complementary uses for a building or for an entire complex of buildings makes it necessary to consider the interdependencies between these forms of use in the analysed decision-making problem, which was not considered in the methods that have so far been developed. In addition, the vast majority of these methods do not take into account the interdependencies between decision-making criteria (which exist in the real world), being limited to a hierarchical structure of the model of the decision-making problems.

The set of criteria that has been proposed is concordant with the consensus on the steps to be followed to ensure sustainable development, as indicated by Throsby [68].

The proposal can be considered universal in how it originally enhances and combines established methods, improving upon them and making their results more reliable and intuitive. However, it must be noted that while the structure is universal, the system elements analysed in the paper are specific to the case presented. This is due to the need to individually select criteria and formulate alternatives for every specific case to which the method is applied.

\section{Conclusion}

Extending the service life of buildings and thereby their life-cycle, particularly concerning historical buildings, is desirable from the point of view of the policy of sustainable development. As buildings age, their functional layouts often become obsolete and require adaptation to be able to function in contemporary times. Such an adaptation, particularly when an entire complex of historical buildings is involved, more often than not features multiple complementary forms of use that must be appropriately selected-which is a complex decision-making problem.

When faced with such problems, decision-makers must act under conditions in which the information they operate with is incomplete, imprecise and uncertain, as it is very difficult, if not outright impossible, to possess complete technical and conservation-related knowledge about any historical building. The nature of this information thus causes it to become difficult to measure when processed by experts. Conflicts can also arise due to the differing preferences of stakeholders, each of whom can have a different outlook on the decision-making criteria being considered in the problem. Decision-makers thus search for support tools that can aid them in the selection of the best manner of adapting historical buildings.

In order to address the problems outlined above, a comprehensive, multi-criteria approach to the selection of a larger number of complementary forms of use for either a single historical building or a complex of such buildings was developed and has been proposed in this paper. A set of universal decision-making criteria that are most often being considered was proposed, of which a part is concordant with the currently popular concept of sustainable development. In order to fully consider the specificity of the decision-making problem being analysed, the authors proposed a network-based structure of the model of internal and external dependencies between criteria and the complementary decision variants concerning forms of use. The authors performed an analysis based on positive and negative impacts between system elements.

The multi-criteria approach that had been proposed by the authors was subjected to operational verification on the example of the adaptation of the Boyen Fortress complex of historical buildings in Giżycko in northern Poland to the proposed complementary forms of use. 
The analysis that had been performed by the authors confirmed the application potential of the proposed approach.

Further studies could focus on introducing more effective methods of processing incomplete and imprecise information that is distinct in the process of decision analyses associated with selecting forms of use for historic buildings. The application of interval sets or fuzzy logic in the modelling the uncertainty of expert opinions in the formulation of assessments based on incomplete and imprecise information about a building can be a promising extension of the present model and decision analysis. Following the trends in the literature as outlined in the introduction, it would be beneficial to develop these methods in this direction. MCDA methods are intended to support decision-makers in making informed choices, aided by experts in specific fields, whose opinions are aggregated to provide clear and intuitive suggestions.

\section{Abbreviations \\ AHP: Analytic hierarchy process; ANP: Analytic network process; BWS: Best- worst scaling; DEMATEL: Decision Making Trial and Evaluation Laboratory; MAVT: Multi-attribute value theory; MCDA: Multi-criteria decision analysis; TOPSIS: Technique for Order Preference by Similarity to an Ideal Solution; WINGS: Weighted Influence Non-linear Gauge System.}

\section{Acknowledgements}

The authors would like to thank IPG sp. z o.o. for sharing information and materials on the subject of the Boyen Fortress in Giżycko.

\section{Authors' contributions}

Conceptualisation: GŚ, BS; methodology: GŚ, BS; validation: GŚ, BS; investigation: GŚ, BS, KB, OK, JB; resources: JB; data curation: GŚ, BS; writing —original draft preparation: $G S, B S, K B$; writing—review and editing, $K B$; visualisation: $O K$, $\mathrm{KB}, \mathrm{BS}$; supervision: GŚ, BS, JB; project administration and conclusion: GŚ, BS. All authors read and approved the final manuscript.

\section{Funding}

The research that went into the preparation of this manuscript has received no external funding.

\section{Availability of data and materials}

The data will be available upon request.

\section{Declarations}

\section{Competing interests}

As authors, we declare that we have no conflicts of interest to disclose.

\begin{abstract}
Author details
'Department of Management in Civil Engineering, Faculty of Civil Engineering, Cracow University of Technology, Kraków, Poland. ${ }^{2}$ Department of Urbanism and the Architecture of City Structures, Cracow University of Technology, Kraków, Poland. ${ }^{3}$ Department of Spatial Planning, Urban and Rural Design, Faculty of Architecture, Cracow University of Technology, Kraków, Poland. ${ }^{4}$ Faculty of Architecture, Cracow University of Technology, Kraków, Poland.
\end{abstract}

Received: 4 May 2021 Accepted: 10 June 2021

Published online: 28 June 2021

\section{References}

1. Borusiewicz W. Konserwacja zabytków budownictwa murowanego (Conservation of masonry monuments). Warsaw: Wydawnictwo Arkady; 1985.

2. Strzelecka E. Rewitalizacja miast w kontekście zrównoważonego rozwoju. Budownictwo i Inżynieria Środowiska. 2011;2:661-8.

3. Di Biase C. Suitable use rather than adaptive reuse: religious heritage in contemporary societies. In: Fiorani D, Kealy L, Musso SF, editors. Conservation-adaptation: keeping alive the spirit of the place. Adaptive reuse of heritage with symbolic value. 2nd ed. Hasselt: EAAE; 2017. p. 55-64.

4. Elsorady DA. Adaptive reuse decision making of a heritage building Antoniadis Palace. Egypt Int J Architect Herit. 2018;14(5):658-77.

5. Skłodowski M. Przykłady analizy wielokryterialnej w ocenie wartośc i ochrony dziedzictwa kultury (Examples of multi-criteria analysis in assessing the values and conservation of cultural heritage). In: Szmygin B, editor. Systemy wartościowania dziedzictwa - stan badań i problemy (Heritage valuation systems - state of research and problems). Warszawa, Lublin: Lubelskie Towarzystwo Naukowe, Międzynarodowa Rada Ochrony Zabytków ICOMOS, Politechnika Lubelska; 2015 p. 209-40 (in Polish).

6. Krawczyk J. Ideał obiektywności wiedzy a początki wartościowania w konserwatorstwie (Ideal of knowledge objectivity versus the beginnings of valuation in conseration). In: Szmygin B, editor. Wartościowanie w ochronie i konserwacji zabytków (Heritage valuation systems - state of research and problems). Warszawa, Lublin: Lubelskie Towarzystwo Naukowe, Międzynarodowa Rada Ochrony Zabytków ICOMOS Politechnika Lubelska; 2012. p. 102-5 (in Polish).

7. Ustinovičius $L$, Jakučionis $S$. Application of multicriteria decision methods in restoration of buildings in the Old Town. Statyba. 2000;6(4):227-36.

8. Dytczak M, Ginda G. Identification of building repair policy choice criteria role. Technol Econ Devel Econ. 2019;15(2):213-28.

9. Dytczak M. Wybrane metody rozwiazywania wielokryterialnych problemów decyzyjnych w budownictwie (Selected methods of solving multi-criteria decision-making problems in construction). Opole: Politechnika Opolska; 2010.

10. Michnik J. Weighted influence non-linear gauge system (WINGS)-An analysis method for the systems of interrelated components. Eur J Operat Res. 2013;228(3):536-44.

11. Paolillo PL, Benedetti A, Baresi U, Terlizzi L, Graj G. An assessment-based process for modifying the built fabric of historic centres: the case of Como in Lombardy. In: Murgante B, Gervasi O, Iglesias A, Taniar D, Apduhan $\mathrm{BO}$, editors. International conference on computational science and its applications. Berlin: Springer; 2011. p. 162-76.

12. Dytczak M, Ginda G. Wybrane wielokryterialne metody wartościowania uwzględniające trudno mierzalność cech zabytków (Selected multi-criteria valuation methods that include hard-to-measure monument characteristics). In: Szmygin B, editor. Systemy wartościowania dziedzictwa - stan badań i problemy (Heritage valuation systems - state of research and problems). Warszawa, Lublin: Lubelskie Towarzystwo Naukowe, Międzynarodowa Rada Ochrony Zabytków ICOMOS Politechnika Lubelska; 2015. p. 39-59 (in Polish).

13. Dutta M, Husain Z. An application of multicriteria decision making to built heritage. The case of Calcutta. J Cultl Herit. 2009;10(2):237-43.

14. Skłodowski M, Dytczak M, Szmelter I. Multicriterial valorization of a monument based on national registry data, heritage protection from documentation to interventions. In: Roko Ž, Rajčić V, Vodopivec B, editors. Proceedings of the EU-CHIC international conference on cultural heritage. Zagreb: Građevinski fakultet; 2012. p. 191-2.

15. Moropoulou A, Chandakas B, Togkalidou T, Karoglou M, Padouvas E. A new methodology for quality control and monitoring of historic buildings: A tool for lifetime engineering. In: Symposium Proceedings, 2nd international symposium, ILCDES integrated life-time engineering of buildings and civil infrastructures. Kuopio: Association of Finnish Civil Engineers RIL; 2003. p. 269-74.

16. Perng YH, Juan YK, Hsu HS. Genetic algorithm-based decision support for the restoration budget allocation of historical buildings. Build Envir. 2007:42(2):770-8.

17. Kim CJ, Yoo WS, Lee UK, Song KJ, Kang KI, Cho H. An experience curvebased decision support model for prioritizing restoration needs of cultural heritage. J Cult Herit. 2010;11(4):430-7. 
18. Tarragüel AA, Krol B, Van Westen B, Van Westen C. Analysing the possible impact of landslides and avalanches on cultural heritage in Upper Svaneti. Georgia J Cult Herit. 2012;13(4):453-61.

19. Delegou ET, Doulamis A, Moropoulou A. Decision making system on the assessment of cleaning interventions using combined fuzzy C-means and neural networks. In: Roko Ž, Rajčić V, Vodopivec B, editors. Proceedings of the EU-CHIC international conference on cultural heritage. Zagreb: Građevinski fakultet; 2012. pp. 191-4.

20. Turskis Z, Zavadskas EK, Kutut V. A model based on ARAS-G and AHP methods for multiple criteria prioritizing of heritage value. Int J Inform Techn Dec Mak. 2013;12(01):45-73.

21. Kutut V, Zavadskas EK, Lazauskas M. Assessment of priority alternatives for preservation of historic buildings using model based on ARAS and AHP methods. Archiv Civil Mech Eng. 2014;14(2):287-94.

22. Vodopivec B, Žarnić R, Tamošaitienè J, Lazauskas M, Šelih J. Renovation priority ranking by multi-criteria assessment of architectural heritage: the case of castles. Int J Strat Prop Manag. 2014;18(1):88-100.

23. Šiožinytė $E$, Antuchevičienė J, Kutut $V$. Upgrading the old vernacular building to contemporary norms: multiple criteria approach. J Civil Eng Manag. 2014:20(2):291-8.

24. Ibáñez AJP, Bernal JMM, de Diego MJC, Sánchez FJA. Expert system for predicting buildings service life under ISO 31000 standard. Application in architectural heritage. J Cult Herit. 2016;18:209-18.

25. Bielniak S. Bilansowanie funkcji w procesie przekształceń zespołów zabytkowych miast (Balancing function in the proces of transforming city heritage complexes). Zeszyty Naukowe Akademii Ekonomicznej w Krakowie. 1992:382:39-46 ((in Polish)).

26. Girard LF, De Toro P. Integrated spatial assessment: a multicriteria approach to sustainable development of cultural and environmental heritage in San Marco dei Cavoti. Italy Cent Eur J Oper Res. 2007;15(3):281-99.

27. Cerreta M, Panaro S, Cannatella D. Multidimensional spatial decisionmaking process: local shared values in action. In: Murgante B, Gervasi O, Misra S, Nedjah N, Rocha AMAC, Taniar D, Apduhan BO, editors. International Conference on Computational Science and Its Applications. Berlin: Springer; 2012. p. 54-70.

28. Tupenaite L, Zavadskas EK, Kaklauskas A, Turskis Z, Seniut M. Multiple criteria assessment of alternatives for built and human environment renovation. J Civil Eng Manag. 2010;16(2):257-66.

29. Doulamis A, Kioussi A, Karoglou M, Matsatsinis N, Moropoulou A. Collec tive intelligence in cultural heritage protection. In: lannides M, Fritsch D, Leissner J, Davies R, Remondino F, Caffo R, editors. Euro-Mediterranean Conference. Berlin: Springer; 2012. p. 310-9.

30. Delegou ET, Kiranoudis C, Sayas J, Moropoulou A. Developing an integrated decision making system for the assessment of cleaning interventions on marble architectural surfaces. In: 12th international congress on deterioration and conservation of stone. New York: Columbia University; 2012.

31. Arroyo Torralvo F, Villegas Sanchez R. An application of multicriteria decision methodology to religious heritage conservation. The case of the cathedral of Jerez de la Frontera (Cádiz). Eur J Sci Theol. 2015;11(2):95-105.

32. Morkunaite Z, Kalibatas D, Kalibatiene D. A Bibliometric data analysis of multi-criteria decision making methods in heritage buildings. J Civ Eng Manag. 2019;25(2):6-99.

33. Pavlovskis M, Migilinskas D, Antucheviciene J, Kutut V. Ranking of heritage building conversion alternatives by applying BIM and MCDM: a case of Sapieha Palace in Vilnius. Symmetry. 2019;11(8):973.

34. Nadkarni RR, Puthuvayi B. A comprehensive literature review of MultiCriteria Decision Making methods in heritage buildings. J Build Eng. 2020;32:5.

35. Zavadskas EK, Antuchevičienè J. Development of an indicator model and ranking of sustainable revitalization alternatives of derelict property: a Lithuanian case study. Sustain Develop. 2006;14(5):287-99.

36. Zavadskas EK, Antuchevičienè J. Multiple criteria evaluation of rural building's regeneration alternatives. Build Environ. 2007;42(1):436-51.

37. Fuentes JM. Methodological bases for documenting and reusing vernacular farm architecture. J Cult Herit. 2010;11(2):119-29.

38. Wang HJ, Zeng ZT. A multi-objective decision-making process for reuse selection of historic buildings. Exp Sys Applic. 2010;37(2):1241-9.
39. Breil M, Giove S, Rosato P. A Multicriteria approach for the evaluation of the sustainability of re-use of historic buildings in Venice. Univ.y Ca' Foscari Venice, Dept Econ Res Pap Ser; 2008; 3/WP/2009.

40. Giove $S$, Rosato P, Breil M. An application of multicriteria decision making to built heritage. The redevelopment of Venice Arsenale. J Mult-Crit Dec Anal. 2010;17(4):85-99.

41. Ferretti $\mathrm{V}$, Bottero M, Mondini G. Decision making and cultural heritage: an application of the Multi-Attribute Value Theory for the reuse of historical buildings. J Cult Herit. 2014;15(6):644-55.

42. Radziszewska-Zielina E, Śladowski G. Supporting the selection of a variant of the adaptation of a historical building with the use of fuzzy modelling and structural analysis. J Cult Herit. 2017;26:53-63.

43. Loli A, Bertolin C. Towards zero-emission refurbishment of historic buildings: a literature review. Build. 2018;8(2):22

44. Zavadskas E, Govindan K, Antucheviciene J, Turskis Z. Hybrid multiple criteria decision-making methods: a review of applications for sustainability issues. Ekonomska Istraživanja. 2020;29(1):857-87.

45. Macías-Bernal JM, Calama-Rodríguez JM, Chávez-de Diego MJ. Modelo de predicción de la vida útil de la edificación patrimonial a partir de la lógica difusa. Informesde la Construcción. 2014;66(533):006.

46. Prieto AJ, Silva A, de Brito J, Macías-Bernal JM, Alejandre FJ. Multiple linear regression and fuzzy logic models applied to the functional service life prediction of cultural heritage. J Cult Herit. 2017;27:20-35.

47. Cabello-Briones C, Prieto AJ, Ortiz P. Determination of the technical suitability of shelters for archaeological sites using fuzzy logic. J Cult Herit. 2020;7:25.

48. Prieto AJ, Turbay I, Ortiz R, Chávez MJ, Macías-Bernal JM, Ortiz P. A fuzzy logic approach to preventive conservation of cultural heritage Churches in Popayán. Colombia Int J Arch Herit. 2020;5:1-20.

49. Affelt WJ. Dziedzictwo techniki jako cząstka kultury Część II. W stronę dziedzictwa zrównoważonego (The Heritage of Technology as a Particle of Culture Part II. Towards Sustainable Heritage). Ochrona Zabytków. 2009;1:53-82 (in Polish).

50. Radziszewska-Zielina E, Śladowski G. Evaluation of historic building conversion options in the context of sustainable development. Techn Trans. 2014;1B:153-64.

51. Roberts FS. Applications of the theory of meaningfulness to psychology. J Mathem Psychol. 1985;29(3):311-32.

52. Saaty TL. Decision making with dependence and feedback: the analytic network process. Pittsburgh: University of Pittsburgh, RWS Publications; 1996.

53. Gabus A, Fontela E. World problems, an invitation to further thought within the framework of DEMATEL, 1-8. Geneva: Battelle Geneva Research Center; 1972.

54. Kapliński O. Metody i modele badań w inżynierii przedsięwzięć budowlanych (Research methods and models in construction project engineering). Warsaw: Polska Akademia Nauk; 2007.

55. Zabawa J. Podejście hybrydowe w analizie ekonomicznej przedsiębiorstwa (Hybrid approach for economic analysis of the firm). Diss. Wrocław: Politechnika Wrocławska Wydział Informatyki i Zarządzania; 2005 (in Polish).

56. Zhou JL, Bai ZH, Sun ZY. A hybrid approach for safety assessment in high-risk hydropower-construction-project work systems. Saf Sci. 2014;64:163-72.

57. Hatefi SM, Tamošaitienè J. An integrated fuzzy DEMATEL-fuzzy ANP model for evaluating construction projects by considering interrelationships among risk factors. J Civ Eng Manag. 2019;25(2):114-31.

58. Vasilenko B. Mamry and the surrounding area. Kętrzyn: Stes; 1996

59. Thorwald J. Iluzja - żołnierze radzieccy w armii Hitlera (Illusion - Soviet soldiers in Hitler's army). Warsaw: PWN; 1994. ((in Polish)).

60. Bogdanowski J. Architektura obronna w krajobrazie Polski. Od Biskupina po Westerplatte. (Defensive architecture in the landscape of Poland. From Biskupin to Westerplatte). Warsaw: PWN; 1996 (in Polish)

61. Bogdanowski J. Zielona Twierdza Boyen (The green Boyen Fortress). Aura. 1998;9:24-5 ((in Polish)).

62. IPG sp. z o.o. Program funkcjonalno-użytkowy: Twierdza Boyen w Giżycku ul. Turystyczna (Function and use programme: Boyen Fortress in Giżycko, 1 Turystyczna Street). Kraków: IPG; 2009;1:13-39 (in Polish).

63. Churchill GA. Marketing research: methodological foundations. 6th ed. San Diego: Harcourt College Publishing; 1995. 
64. Vorobiev P, Holownia M, Krasnova L. Multi-criteria decision analysis (MCDA) and its alternatives in health technology assessment. J Health Pol Outc Res. 2015;1:34-43.

65. Belton $V$, Stewart T. Problem structuring and multiple criteria decision analysis. In: Ehrgott M, Figueira JR, Greco S, editors. Trends in multpile criteria decision analysis. Boston: Springer; 2010. p. 209-39.

66. Van Schoubroeck S, Springael J, Van Dael M, Malina R, Van Passel S. Sustainability indicators for biobased chemicals: A Delphi study using Multi-Criteria Decision Analysis. Resourc Cons Recycl. 2019;144:198-208.

67. Kendall MG, Gibbons JD. Rank correlation methods. New York, NY: Oxford University Press; 1990
68. Throsby D. Cultural capital and sustainability concepts in the economics of cultural heritage. In: de la Torre M, editor. Assessing the values of cultural heritage. Los Angeles: Getty Conservation Institute; 2002. p. 101-7.

\section{Publisher's Note}

Springer Nature remains neutral with regard to jurisdictional claims in published maps and institutional affiliations.

\section{Submit your manuscript to a SpringerOpen ${ }^{\circ}$ journal and benefit from:}

- Convenient online submission

- Rigorous peer review

- Open access: articles freely available online

- High visibility within the field

Retaining the copyright to your article

Submit your next manuscript at $\boldsymbol{\nabla}$ springeropen.com 